\title{
Pengaruh beberapa Jenis Media Tanam terhadap Produksi Bunga Petunia Grandiflora (Petunia grandiflora Juss.) dalam Sistem Soilless Culture
}

\author{
Ilham Fairuz Tirta Aji1), Nugraheni Widyawati1)
}

\begin{abstract}
Nowadays urban and rural communities have an interest in choosing a place to live or a comfortable and fresh environment. The purpose of this research was to study the type of planting media other than soil that can support flowering of petunia plants. The research was conducted in Salaran experimental field, Satya Wacana Christian University, Wates Village, Getasan District, Semarang Regency from August-October 2018. The research used Randomized Block Design with 6 treatment and 4 replications. Media types were: P1 (rockwool), P2 (raw husk), P3 (charcoal husk), P4 (bricks), P5 (cocopeat) and P6 (zeolite). Parameters considered include plants, number of leaves, number of productive branches, stem diameter and number of flowers. Data were analyzed using Variant Analysis (ANOVA) followed by Honestly Significant Difference Test with $95 \%$ confidence interval adn correlation test. This research showed that zeolite growing media was able to support flowering of petunia plants with the highest average number of flowers (6.17) followed by brick planting media (5.38). Productivity of petunia per plant is closely related to plant height, number of leaves, productive branches, but not closely related to stem diameter.
\end{abstract}

Keywords: Growing Media, Petunias, Soilless Culture

\section{PENDAHULUAN}

Budidaya tanaman hias bunga petunia secara konvensional dilakukan di lahan halaman rumah atau ditanam dalam pot. Penanaman konvensional ini membutuhkan tanah yang subur. Salah satu kendala dari penanaman secara konvensional di perkotaan adalah semakin sulit mendapatkan tanah yang subur, semakin banyak permukaan tanah yang tertutup paving atau beton atau batu atau aspal dan semakin sempit lahan yang bisa untuk berkebun. Salah satu alternatif solusinya adalah menanam petunia tanpa menggunakan tanah yang disebut soilless culture.

Jenis - jenis media tanam soilless culture yang umum digunakan pada hidroponik yaitu rockwool, sekam mentah, arang sekam, batu bata, zeolit, pasir, cocopeat dan yang lainnya. Keunggulan dari soilless culture selain tidak tergantung pada ketersediaan tanah yang subur adalah: penampilan nampak lebih bersih; dapat dirancang secara vertikal; tidak melakukan penyiraman setiap hari; tanaman tidak mudah mengalami kekeringan/kekurangan air; terhindar dari soilborn desease; terhindar dari gulma; pemupukan dan penggunaan air lebih efisien. Setiap jenis media tanam dalam soilles culture memiliki kelebihan dan kekurangan masing masing dalam fungsinya sebagai media tanam. Sejauh ini belum banyak diketahui respon tanaman bunga petunia jika ditanam secara soilles culture menggunakan media tanam rockwool; batu bata; sekam; arang sekam; cocopeat; zeolit. Oleh karena itu, masih diperlukan adanya penelitian terkait budidaya petunia secara soilles culture.

Tujuan penelitian ini adalah untuk mengetahui pengaruh jenis media terhadap produksi bunga petunia dan jenis media yang menghasilkan bunga yang paling

1) Fakultas Pertanian dan Bisnis Universitas Kristen Satya Wacana, Salatiga

Author contact: heniwidya@gmail.com banyak, serta parameter pertum buhan yang mempengaruhi produksi bunga petunia. Hasilnya diharapkan dapat dijadikan sebagai salah satu referensi dalam budidaya tanaman petunia secara soilless culture.

\section{BAHAN DAN METODE}

Penelitian dilakukan di Kebun Percobaan Salaran, Fakultas Pertanian Universitas Kristen Satya Wacana di Desa Wates, Kecamatan Getasan, Kabupaten Semarang yang berada pada ketinggian \pm 900 meter diatas permukaan laut. Penelitian ini dimulai pada bulan Agustus-Oktober 2018. Penelitian ini menggunakan Rancangan Acak Kelompok (RAK) terdiri dari 6 perlakuan masing - masing diulang 4 kali. Perlakuan yang dipakai adalah beberapa jenis media seperti P1: rockwool, P2: sekam mentah, P3: arang sekam, P4: batu bata, P5: cocopeat, P6: batu zeolit. Variabel pengamatan meliputi: waktu kemunculan bunga, tinggi tanaman, jumlah dun, jumlah bunga, jumlah cabang primer, diameter batang utama. Analisis data diolah menggunakan Analysis of Varian (ANOVA) yang dilanjutkan dengan Uji Beda Nyata Jujur (BNJ) dengan tingkat kepercayaan $95 \%$ yang diteruskan dengan uji korelasi.

\section{HASIL DAN PEMBAHASAN}

\section{Pengaruh jenis media tanam terhadap pembungaan tanaman petunia}

Pengamatan jumlah bunga dimulai pada umur 0 hari sampai dengan 56 hari setelah transplanting, dilakukan setiap seminggu sekali. Media tanam berpengaruh terhadap pembungaan tanaman petunia. Grafik kemunculan bunga tanaman petunia selama 56 hari setelah t ransplanting dapat dilihat dalam Gambar 1.

Berdasarkan grafik rerata jumlah bunga yang muncul, kenaikan jumlah bunga atau munculnya bunga mulai terjadi pada umur 21 hari setelah transplanting. Pada umur 21 HST - 56 HST perlakuan batu bata dan zeolit mengalami kenaikan yang cukup cepat. Hal ini diduga media batu bata dan zeolit memiliki kemampuan yang 
baik dalam menyerap air dan unsur hara. Batu bata dan zeolit juga memiliki kemampuan drainase dan aerasi yang baik. Hal ini didukung oleh pernyataan lqbal (2016), pecahan batu bata juga dapat digunakan sebagai media tanam, memiliki kemampuan drainase dan aerasi yang baik. Pemakain pecahan batu bata dan zeolit lebih ditujukan untuk menopang tanaman dan untuk melekatkan akar.

Media yang lain seperti rockwool, sekam mentah, arang sekam, cocopeat kemunculan bunga terlihat tidak konstan. Pada media rockwool, sekam mentah dan arang sekam terlihat penurunan jumlah bunga pada umur 49 - 56 hari setelah transplanting. Penurunan jumlah bunga pada media sekam mentah disebabkan karena tanaman pada media tersebut sudah mulai layu dan menyebabkan bunga yang terbentuk rontok. Hal ini karena pertumbuhan tanaman yang terbilang lambat. Media sekam mentah terlihat penambahan bunga paling rendah dari media lainnya. Kemampuan media untuk menyimpan larutan nutrisi akan berpengaruh pada ketersediaan hara dalam media. Ketersediaan hara rendah akan menghambat proses fisiologis tanaman (Junita et al. 2002).

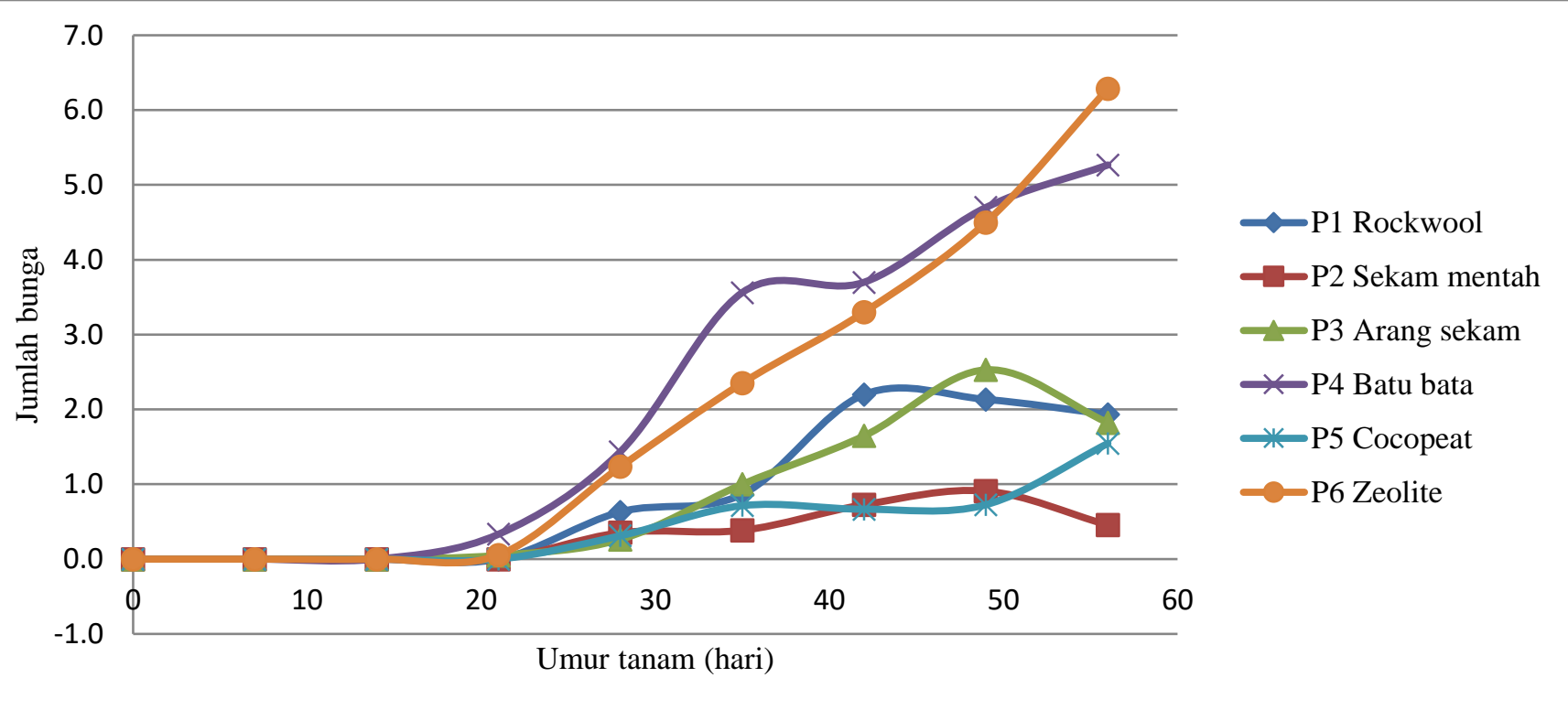

Gambar 1 Grafik kemunculan bunga dari 0 hari sampai 56 hari

Tabel 1 Pengaruh jenis media terhadap jumlah bunga pada umur 56 hari setelah transplanting

\begin{tabular}{lc}
\hline Perlakuan & Jumlah bunga \\
\hline P1 (rockwool) & $1,97 \mathrm{~b}$ \\
P2 (sekam mentah) & $0,42 \mathrm{~b}$ \\
P3 (arang sekam) & $2,00 \mathrm{~b}$ \\
P4 (batu bata) & $5,38 \mathrm{a}$ \\
P5 (cocopeat) & $1,44 \mathrm{~b}$ \\
P6 (zeolit) & $6,17 \mathrm{a}$ \\
\hline
\end{tabular}

Keterangan: Angka yang diikuti oleh huruf sama menunjukan tidak beda nyata

Pada Tabel 1. menunjukan hasil bahwa berbagai media tanam memberikan pengaruh nyata terhadap jumlah bunga. Kemudian dapat dilihat hasil perlakuan P6 dan P4 yang tidak berbeda nyata terhadap jumlah bunga dengan hasil 6,17 dan 5,38 akan tetapi kedua media tersebut berbeda nyata terhadap P1, P2, P3 dan P5. Media zeolit mempunyai kelebihan bila digunakan sebagai media hidroponik. Kelebihannya antara lain mempunyai porositas yang baik, tahan lama dan dapat menyerap pupuk dan mengeluarkannya sesuai kebutuhan tanaman. Setiap penambahan jumlah bunga, terjadi pula peningkatan jumlah daun, anakan daun, dan jumlah cabang produktif (March dan Arifin, 2013).

Media sekam mentah menghasilkan rata-rata jumlah bunga paling rendah hal ini karena media sekam mentah mudah kering sehingga tidak mendukung ketersediaan unsur hara yang terlarut dalam air bagi tanaman. Hal ini didukung oleh pernyataan Perwtasari et al. (2012) bahwa media sekam mentah memiliki pori-pori yang besar akan mengakibatkan penguapan yang berlebih pada media. Pada suhu tinggi sekam mentah cepat kering karena tidak mampu menahan evaporasi tinggi yang mengakibatkan pertumbuhan tanaman terhambat

Unsur hara $\mathrm{P}$ yang terdapat pada larutan nutrisi diserap baik oleh media untuk kebutuhan suplai tanaman. Fosfor diperlukan untuk pembentukan bunga dan buah (Lingga, 2006). Fosfor dan kalium membantu membentuk bunga dan buah serta mendorong akar agar memperkuat tanaman. Bunga sebagai tempat penyimpanan karbohidrat dan pada saat itu aka $\mathrm{n}$ terjadi penurunan pertumbuhan. Semakin banyak jumlah bunga maka tanaman menyerap unsur hara akan semakin tinggi. Menurut Imam (2016), unsur hara fosfor bagi tanaman sangat penting yaitu merangsang pertumbuhan akar dan juga berfungsi sebagai bahan mentah untuk membentuk protein, membantu asimilasi dan respirasi serta mempercepat pembungaan dan pemasakan biji.

\section{Parameter pertumbuhan yang menunjang produksi bunga tanaman petunia}

Produktifitas tanaman sangat dipengaruhi oleh pertumbuhan vegetatif, dimana pertumbuhan vegetatif sangat penting agar saat tanaman memasuki fase generatif dapat menghasilkan produktifitas yang tinggi. Uji korelasi menunjukan hampir seluruh parameter 
penting dalam pertumbuhan tanaman petunia menunjukan nilai korelasi yang sangat signifikan (Tabel 2). Hasil analisis korelasi antara parameter tinggi tanaman dengan jumlah bunga mendapatkan nilai 0,761 yang artinya parameter tinggi dengan jumlah bunga memiliki korelasi yang sangat kuat. Sangat kuatnya korelasi hubungan antar parameter dilihat pada Tabel 2 yang artinya jika nilai variabel atau parameter petumbuhan $X$ naik, maka variabel $Y$ juga ikut naik. Hal ini sejalan dengan pendapat widodo et al. (2017) tinggi rendahnya hasil dari tinggi tanaman juga dipengaruhi oleh perakaran yang belum sepenuhnya aktif menyerap unsur hara. Selain itu larutan nutrisi yang tersedia dapat mempengaruhi metabolisme tanaman seperti kecepatan fotosintesis tanaman, aktivitas enzim dan potensi penyerapan ion-ion larutan oleh akar tanaman (Sutiyoso, 2009).

Tabel 2. Korelasi beberapa variabel pengamatan terhadap jumlah bunga

\begin{tabular}{lc}
\hline Parameter yang diamati & $\begin{array}{c}\text { Nilai korelasi dengan } \\
\text { parameter jumlah } \\
\text { bunga }\end{array}$ \\
\hline Tinggi $(\mathrm{cm})$ & 0,761 \\
Jumlah daun (helai) & 0,847 \\
Jumlah cabang primer & 0,728 \\
Diameter batang utama $(\mathrm{cm})$ & 0,543 \\
\hline
\end{tabular}

Tanaman petunia akan berbunga banyak jika daun yang dibutuhkan untuk menyediakan kebutuhan hidupnya tersedia dalam jumlah dan ukuran yang sesuai. Tanaman petunia dengan jumlah daun yang banyak akan memberikan pasokan asimilat yang banyak dengan syarat bahwa daun-daun tersebut mendapat intensitas yang cukup untuk melakukan fotosintesis. Pada Tabel 2. dapat dilihat jika nilai koreasi jumlah daun dengan jumlah bunga sebesar 0,847 menunjukkan keeratan sangat kuat antara dua variabel yang diamati dimana semakin banyak daun maka didukung dengan banyaknya jumlah bunga yang muncul. Unsur hara yang tersedia dapat merangsang perumbuhan vegetatif tanaman. Unsur hara nitrogen yang tercukupi dapat merangsang pertumbuhan tanaman terutama batang, cabang dan daun. Berbagai persenyewaan organik lainnya dan unsur $P$ dibutuhkan tanaman dalam pembelahan sel serta unsur $\mathrm{K}$ yang merupakan pengaktif dari sejumlah enzim yang penting untuk proses fotosintesis dan respirasi (Marginingsih et al. 2018).

Pada Tabel 2. dapat dilihat jika nilai koreasi jumlah cabang dengan jumlah bunga sebesar 0,728 menunjukkan keeratan yang kuat antara dua variabel yang diamati dimana semakin banyak jumlah bunga yang muncul maka didukung oleh bertambahnya cabang produktif. Hal ini diperkuat oleh penelitian Surtinah (2018), bahwa semakin banyaknya cabang produktif yanag terbentuk maka jumlah polong kedelai juga semakin banyak dan kesempatan untuk munculnya bunga akan semakin besar. Menurut penelitian (March dan Arifin, 2013), indikasi setiap bibit tanaman kemuning berbunga, akan menambah jumlah cabang. Penyebab fenomena ini diduga berhubungan dengan pengatur pertumbuhan.
Diameter batang didefinisikan sebagai panjang garis antara dua buah titik pada lingkaran di sekeliling batang yang melalui titik pusat sumbu batang. Pada Tabel 2 dapat dilihat jika nilai koreasi diameter batang dengan jumlah bunga sebesar 0,543 menunjukkan kurang erat antara dua variabel yang diamati. Hal ini diduga tanaman fokus melakukan fotosintesis di daun dan menghasilkan fotosintat yang digunakan untuk kebutuhan tanaman. Menurut Rizqiani dkk (2007) tanaman melakukan fotosintesis dalam jumlah besar yang mengakibatkan jumlah fotosintat terbentuk lebih banyak yang digunakan untuk memacu produktifitas tanaman.

\section{KESIMPULAN}

1. Jenis media tanam rockwool; sekam; arang sekam; batu bata; zeolit dan cocopeat berpengaruh terhadap pembungaan tanaman petunia.

2. Media tanam yang paling mendukung produksi tanaman bunga petunia adalah media zeolit dengan rata-rata jumlah bunga sebesar 6,17 diikuti oleh media batu bata dengan hasil rata-rata jumlah bunga sebesar 5,38.

3. Produksi bunga petunia yang tinggi didapatkan dari pertumbuhan vegetatif yang baik, produksi bunga petunia berhubungan erat dengan tinggi tanaman, jumlah daun, jumlah cabang produktif, tetapi kurang erat hubungannya dengan diameter batang.

\section{DAFTAR PUSTAKA}

Imam, M. A. 2016. Pengaruh jumlah benih perlubang dan interval pemberian pupuk NPK terhadap pertumbuhan dan produksi tanaman kedelai (Glicine $\operatorname{Max}($ L.) Merrill). J. Saintis 8(1): 1-18.

lqbal, M. 2016. Simpel hidroponik. Edisi 1. Lily Publisher, Yogyakarta.

Junita, F., Sri M dan Dody K. 2002. Pengaruh frekuensi penyiraman dan takaran pupuk kandang terhadap pertumbuhan dan hasil pakchoi. J. Ilmu Pertanian. IX(1).

Lingga, P. 2006. Hidroponik bercocok tanam tanpa tanah. Edisi revisi. Penebar Swadaya, Jakarta

March S. R. dan Arifin A, S. 2013. Hubungan jumlah bunga, jumlah daun, jumlah anak daun, jumlah cabang, dan tinggi tanaman terhadap pertumbuhan bibit tanaman kemuning (Murraya paniculata (L.) Jack). J. Lanskap Indonesia 5(1) : 23-25.

Marginingsih, R. S., A. S. Nugroho., dan M. A. Dzakiy. 2018. Pengaruh substansi pupuk organic cair pada nutrisi $A B$ mix terhadap pertumbuhan caisim (Brassica juncea L.) Pada hidroponik drip irrigation system. J. Biologi dan Pembelajarannya 5(1) : 44-51.

Perwitasari, B., Mustika T. dan Catur W. 2012. Pengaruh media tanam dan nutrisi terhadap pertumbuhan dan hasil tanaman pakchoi (Brassica juncea L.) dengan sistem hidroponik. J. Agrovigor 5(1) : 1-12.

Risqiani, N. F., Ambarwati, E., dan Yuwono, N.W. 2007. Pengaruh dosis dan frekuensi pemberian pupuk organik cair terhadap pertumbuhan dan hasil tanaman buncis (Phaesolus vulgaris L.) dataran rendah. J. Ilmu Tanah dan Lingkungan $7: 43-53$. 
Agrosains 21(2): 25-28, 2019; pISSN: 1411-5786; elSSN: 2655 - 7339

Sutiyoso, Y. 2009. Hidroponik Ala Yos. Penebar Swadaya, Jakarta.

Widodo, S., Suoriyono, dan T. Irawatai . 2017. Pengaruh umur bibit dan umur panen terhadap pertumbuhan dan produksi hidroponik nft tanaman selada (Lactuca sativa L.) varietas grand rapids. J. Hijau Cendekia. 2(2): 21-26. 